Research Paper

\title{
Discrepancy between Serological and Virological Analysis of Viral Hepatitis in Hemodialysis Patients
}

Jer-Ming Chang1,2,5, Chung-Feng Huang 3,6, Szu-Chia Chen ${ }^{1,2,4}$, Chia-Yen Dai33,4, Ming-Lun Yeh33, Jee-Fu

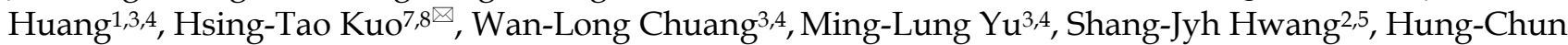
Chen $2,5 \bowtie$

1. Department of Internal Medicine, Kaohsiung Municipal Hsiao-Kang Hospital, Kaohsiung, Taiwan;

2. Division of Nephrology, Department of Internal Medicine, Kaohsiung Medical University Hospital, Kaohsiung Medical University, Kaohsiung, Taiwan;

3. Hepatology, Department of Internal Medicine, Kaohsiung Medical University Hospital, Kaohsiung Medical University, Kaohsiung, Taiwan;

4. Faculty of Medicine, College of Medicine, Kaohsiung Medical University, Kaohsiung, Taiwan;

5. Renal Care, College of Medicine, Kaohsiung Medical University, Kaohsiung, Taiwan;

6. Department of Occupational Medicine, Kaohsiung Municipal Ta-Tung Hospital, Kaohsiung, Taiwan;

7. Division of Hepatogastroenterology, Department of Internal Medicine, Chi-Mei Medical Center, Tainan, Taiwan;

8. Department of Senior Citizen Service Management Chia Nan University of Pharmacy \& Science, Tainan, Taiwan.

$\triangle$ Corresponding authors: Hsing-Tao Kuo, M.D. Division of Gastroenterology and Hepatology, Department of Internal Medicine, Chi Mei Medical Center, 901 Chung-Hwa Rd, Yung-Kang City, Tainan 710, Taiwan. Tel: 8866 2812811; Fax: 88662828928 E-mail: kht@mail.chimei.org.tw And Hung-Chun Chen, M.D. Ph.D. Division of Nephrology, Kaohsiung Medical University Hospital, Kaohsiung Medical University. 100 Shih-Chuan 1st Rd, Kaohsiung 807, Taiwan Tel: +886 73121101 ext 7351; Fax: +886 7322872133 E mail: chenhc@kmu.edu.tw.

( ) Ivyspring International Publisher. This is an open-access article distributed under the terms of the Creative Commons License (http://creativecommons.org/ licenses/by-nc-nd/3.0/). Reproduction is permitted for personal, noncommercial use, provided that the article is in whole, unmodified, and properly cited.

Received: 2013.12.02; Accepted: 2014.02.18; Published: 2014.03.08

\begin{abstract}
Background and Aim: Viral hepatitis is a health threat for hemodialysis (HD) patients and it may be transmitted during treatment. Some patients categorized to have viral hepatitis were found to be non-viremic. To clarify the discrepancy between the serological tests in HD patients, we conducted the study.

Methods: A total of $168 \mathrm{I}$ HD patients was included. Blood samples were analyzed for hepatitis B surface antigen ( $\mathrm{HBsAg}$ ) and anti-hepatitis $\mathrm{C}$ antibody (anti-HCV). Detection of hepatitis $B$ virus (HBV) DNA and hepatitis $\mathrm{C}$ virus (HCV) RNA were performed in either $\mathrm{HBsAg}(+)$ or anti-HCV $(+)$ samples. HBV DNA/HCV RNA was also measured in a subset of $\mathrm{HBsAg}(-)$ and anti-HCV (-) patients. Liver function tests were analyzed and compared with the serological and virological tests.

Results: The serological tests showed that 230 patients (13.7\%) were $\mathrm{HBsAg}(+)$ and $290(17.3 \%)$ were anti-HCV (+). We were unable to detect HBV DNA in 97 of $230(42.2 \%) \mathrm{HBsAg}(+)$ patients, and HCV RNA could not be found in 76 of $290(26.2 \%)$ anti-HCV (+) patients. In $167 \mathrm{HBsAg}(-)$ patients, only one showed a trace amount of HBV DNA. None of I5I anti-HCV (-) patients showed detectable HCV RNA. The prevalence rate of viral hepatitis remains high in Taiwanese HD patients: $13.7 \%$ for HBV and $17.3 \%$ for HCV. However, virological analysis showed $42.2 \%$ non-viremic rate for $\mathrm{HBsAg}$ and $26.2 \%$ non-viremic rate for anti-HCV.

Conclusions: The findings might challenge the presently suggested principles of bed and machine dedication and the diagnosis of viral hepatitis in HD patients.
\end{abstract}

Key words: hepatitis B virus; hepatitis C virus; hemodialysis; viremia. 


\section{Introduction}

Asia is classified as a high endemic area for hepatitis $B$ virus (HBV) and hepatitis $C$ virus (HCV) infections (1). Routes of transmission for HBV and HCV might vary, but both could be transmitted through blood-borne and mucosal routes. Prevalence of both HBV and HCV are notably higher in hemodialysis (HD) patients than in the general population $(2$, $3)$, contributed mostly by blood transfusions in the pre-erythropoietin era and also the nature of extracorporeal blood exposure. By the year 2000, a survey of national HD cohorts in Taiwan showed a positive rate of $10.6 \%$ for hepatitis B surface antigen (HBsAg) and $26.5 \%$ for HCV antibody (anti-HCV) (4). It was suggested that the high prevalence rate of chronic $\mathrm{HBV} / \mathrm{HCV}$ hepatitis explained the higher morbidity and mortality caused by liver cirrhosis (LC) and hepatocellular carcinoma (HCC) in HD patients $(5,6)$. To lessen the health threat, the Taiwan Society of Nephrology launched practice guidelines for HD, and proposed strict infection control measures and suggested beds/machines dedication for both HBsAg $(+)$ and anti-HCV $(+)$ patients (7). Its beneficial results were reflected by the low annual sero-conversion rate in recent years: $0.25 \%$ for HBsAg and $0.72 \%$ for anti-HCV.

At present, the diagnosis of $\mathrm{HBV}$ and $\mathrm{HCV}$ infection is largely based on examining either the presence of circulating serological markers of HBV particles (most commonly HBsAg) or anti-HCV antibody before the 1990s, when the methods to detect HBV DNA and HCV RNA were unavailable $(8,9)$. With advancement of biotechnology, diagnosis of viral diseases has been brought to another level. Furthermore, it is the viral load in the blood that monitors the antiviral treatment response, but not the titers of viral particle markers or viral antibodies. Past literature had revealed significant false negative rates of the serological methods to diagnose active $\mathrm{HBV}$ and $\mathrm{HCV}$ infections (10-12). A serious issue is these false-negative but potentially infectious patients could be unintentionally assigned to the beds next to true hepatitis-free patients. Oppositely, false positive examinations were occasionally noted in some patients with positive serological tests but no detectable virus in their blood. Considering the utmost importance to prevent the transmission of viral hepatitis during HD, it is necessary to clarify the discrepancy between the serological tests and the more updated $\mathrm{HBV} / \mathrm{HCV}$ virological examinations. Significance of the present study might urge nephrology practitioners to re-define the exact prevalence of viral hepatitis in HD patients. It would also be very useful to formulate a practical strategy of infection control in HD institutes, especially for those areas with high prevalence rate of viral hepatitis and where bed/machine dedication has been suggested.

\section{Patients and methods}

\section{Patient enrollment and blood tests for viral hepatitis}

A total of 1902 patients who received HD for at least six months (ranging from seven months to twenty six years, with a median of 6.7 years) were recruited from fifteen institutes, including one medical center, three regional hospitals, and eleven dialysis clinics in southern Taiwan. Patients who rejected giving the informed consent and those who were in acute illness were excluded, and finally 1681 prevalent patients were included for this study. All patients received 3.5-4.5 hours per session, three sessions per week maintenance HD. Of the 1559 patients with known primary renal diseases, the causes of renal failure were as followed: chronic glomerulonephritis $(\mathrm{n}=644,41.3 \%)$, diabetic nephropathy $(\mathrm{n}=579,37.1 \%)$, hypertensive renal disease $(\mathrm{n}=88,5.6 \%)$, lupus nephropathy $(n=28,1.8 \%)$, gouty nephropathy $(n=25$, $1.6 \%)$, obstructive nephropathy $(\mathrm{n}=23,1.5 \%)$, polycystic kidney disease $(n=28,1.8 \%)$ and others $(n=144$, $8.6 \%$ ). All the eligible subjects were tested for both anti-HCV and HBsAg examinations. The processing of all the samples in our study followed a regulated rule, and analyzed in a same laboratory by the same technician specialized in viral hepatitis nucleic acid measurement. Pre-HD blood samples were collected monthly in the period between January, 2011 and January, 2012. Only patients testing positive for HBsAg or anti-HCV at least twice within 6 months were eligible for the study. HBsAg was determined by using a standard chemiluminescent microparticle immunoassay (ARCHITECT HBsAg, Abbott Diagnostics). Anti-HCV was examined using a third-generation enzyme immunoassay (Abbott Laboratories, North Chicago, IL). HBV DNA was determined by a standardized automated quantitative polymerase chain reaction assay (COBAS TaqMan HBV test; Roche Diagnostics; detection limit 12 $\mathrm{IU} / \mathrm{ml}$ ) (13). HCV RNA was measured by a real-time polymerase chain reaction assay (RealTime $\mathrm{HCV}$; Abbott Molecular, Des Plaines IL, USA; detection limit: $12 \mathrm{IU} / \mathrm{ml}$ ) (14). All the above-mentioned tests were duplicated for each tested sample.

In a subset of the included patients (from Kaohsiung Municipal Hsiao-Kang Hospital), we also performed HBV DNA detection for $167 \mathrm{HBsAg}(-)$ patients, and HCV RNA detection for 151 anti-HCV (-) patients in order to make sure if the possibility of false negative serological reaction existed as previ- 
ously reported in the literature, probably because of using older versions of serological assays (10-12).

\section{Ethics Statement}

The study protocol was approved by the institutional review board of the Kaohsiung Medical University Hospital (KMUH-IRB-980083). Informed consents have been obtained in written form from patients and all clinical investigation was conducted according to the principles expressed in the Declaration of Helsinki. The patients gave consent for the publication of the clinical details.

\section{Correlation of serological and virological examinations with liver function test}

In Taiwan, HD patients receive routine monthly biochemical tests, including aspartate aminotransferase (AST) and alanine aminotransferase (ALT). Results of the serological and virological tests were analyzed along with the six-month average AST/ALT levels.

\section{Statistical analyses}

Frequency was compared between groups using the $X^{2}$ test, with the Yates correction, or Fisher exact test. Group means, presented as mean values standard deviation, were compared using analysis of variance and the Student $t$-test. The statistical analyses were performed using the SPSS 12.0 statistical package (SPSS, Chicago, IL, USA). All statistical analyses were based on two-sided hypothesis tests with a significance level of $\mathrm{p}<0.05$.

\section{Results}

Table 1 shows the demographic data of all the enrolled patients. Of the 1681 enrolled patients, 230 $(13.7 \%)$ were positive for HBsAg and 290 patients $(17.3 \%)$ were positive for anti-HCV. Also shown are the baseline characteristics of patients who were tested positive or negative for HBsAg or anti-HCV.
Patients positive for HBsAg or anti-HCV were older, had longer dialysis vintage and higher hepatic enzyme levels.

\section{Difference between the serological and virological examinations}

As shown in Table 2, HBV DNA was undetectable in 97 of $230(42.2 \%)$ HBsAg $\left(^{+}\right)$patients, and HCV RNA was undetectable in 76 of $290(26.2 \%)$ anti-HCV $(+)$ patients. The findings signified that the current updated serological methods to diagnose $\mathrm{HBV} / \mathrm{HCV}$ hepatitis failed to demonstrate HBV viremia in $42.2 \%$ and $\mathrm{HCV}$ viremia in $26.2 \%$ of HD patients. In other words, the positive predictive value of HBsAg test to validate $\mathrm{HBV}$ viremia was $57.8 \%$, and $73.8 \%$ for $\mathrm{HCV}$ viremia.

Samples in a subset of HBsAg (-)/anti-HCV (-) patients received virus detection tests in order to avoid potential virus transmission due to the possibility of false negative serological tests. None of the 151 anti-HCV (-) patients was found to have circulating HCV RNA. Only one out of $167 \mathrm{HBsAg}(-)$ patients gave weak positive reaction of HBV DNA, but the copy number was only slightly above the detection limit. Repeated examination for this patient showed a negative reaction. Unlike the previous reports (10-12), the presently used serological assays did not report any incidence of unnoticed viremia, at least in this subset of patients.

HBsAg $(+)$ and 290 anti-HCV (+) patients made a total of 520 in our cohort. Among them, 41 (7.88\%) patients were $\mathrm{HBsAg}(+)$ plus anti-HCV $(+)$. Twenty of the $41(48.7 \%)$ were negative for HBV DNA and 12 of the $41(29.2 \%)$ were negative for HCV RNA. Both of the percentages were higher than patients with only HBV $(42.2 \%)$ and with only HCV (26.2\%), but not very different. The AST/ALT levels in this dual-infected group of patients were similar to other patients with only HBV or HCV.

Table I. Basic demographical, virological, and clinical features of the enrolled I68I HD patients.

\begin{tabular}{|c|c|c|c|c|c|}
\hline & & & $\mathrm{Ag}$ & & $\mathrm{HCV}$ \\
\hline Parameter & All & $(+), n=230$ & $(-), n=1451$ & $(+), n=290$ & $(-), n=1391$ \\
\hline Age (years), mean $\pm S D$ & $62.2 \pm 12.9$ & $63.8 \pm 10.9$ & $57.9 \pm 14.4$ & $63.6 \pm 16.0$ & $59.0 \pm 13.7$ \\
\hline Male, n (\%) & $824(49.0)$ & $126(54.8)$ & $698(48.1)$ & $122(42.0)$ & $702(50.5)$ \\
\hline BMI $\left(\mathrm{kg} / \mathrm{m}^{2}\right)$, mean \pm SD & $22.5 \pm 4.0$ & $25.5 \pm 14.2$ & $22.1 \pm 5.5$ & $22.0 \pm 6.2$ & $22.9 \pm 4.7$ \\
\hline AST (IU/L), mean \pm SD & $20.6 \pm 11.2$ & $25.5 \pm 14.2$ & $19.8 \pm 10.1$ & $26.2 \pm 13.5$ & $19.4 \pm 10.3$ \\
\hline ALT (IU/L), mean \pm SD & $19.4 \pm 15.6$ & $31.0 \pm 11.1$ & $16.7 \pm 8.8$ & $26.3 \pm 18.4$ & $17.9 \pm 14.6$ \\
\hline White blood cell count $\left(\times 10^{3} \mathrm{~L}\right)$, mean \pm SD & $6.69 \pm 2.48$ & $5.79 \pm 2.20$ & $6.71 \pm 3.01$ & $6.11 \pm 2.64$ & $6.83 \pm 2.32$ \\
\hline Hemoglobin $(\mathrm{g} / \mathrm{dL})$, mean \pm SD & $10.5 \pm 1.3$ & $9.7 \pm 2.0$ & $10.7 \pm 1.6$ & $11.0 \pm 2.2$ & $10.1 \pm 1.5$ \\
\hline Platelet count $\left(\times 10^{3} \mathrm{~L}\right)$, mean $\pm \mathrm{SD}$ & $193 \pm 64$ & $177 \pm 99$ & $198 \pm 55$ & $168 \pm 72$ & $201 \pm 47$ \\
\hline Diabetes, $\mathrm{n} / \mathrm{N}(\%) \#$ & $608 / 1560(39.0)$ & $78(33.9)$ & $530(36.5)$ & 115(39.6) & $493(35.4)$ \\
\hline Dialysis vintage(years), median & 6.7 & 11.6 & 4.4 & 10.5 & 5.3 \\
\hline
\end{tabular}

Note: SD: standard deviation; BMI: body mass index; AST: aspartate aminotransferase; ALT: alanine aminotransferase

\# clinical history available in 1560 patients. 
Table 2. Correlation of HBsAg and HBV DNA, and of anti-HCV and HCV RNA with liver function tests.

\begin{tabular}{|c|c|c|c|c|c|c|}
\hline & & & \multicolumn{4}{|c|}{ HBsAg (+) } \\
\hline & $\begin{array}{l}\text { HBsAg }(-) \\
(n=1451,86.3 \%)\end{array}$ & $\begin{array}{l}\operatorname{HBsAg}(+) \\
(\mathrm{n}=230,13.7 \%)\end{array}$ & $P$ value & $\begin{array}{l}\text { HBV DNA (-) } \\
(\mathrm{n}=97,42.2 \%)\end{array}$ & $\begin{array}{l}\text { HBV DNA }(+) \\
(\mathrm{n}=133,57.8 \%)\end{array}$ & $P$ value \\
\hline AST (IU/L), mean \pm SD & $19.8 \pm 10.1$ & $25.5 \pm 14.2$ & $<0.05$ & $18.6 \pm 9.7$ & $30.8 \pm 9.9$ & $<0.001$ \\
\hline \multirow[t]{3}{*}{ ALT (IU/L), mean \pm SD } & $16.7 \pm 8.8$ & $31.0 \pm 11.1$ & $<0.001$ & $17.2 \pm 12.0$ & $34.3 \pm 10.3$ & $<0.001$ \\
\hline & & & \multicolumn{4}{|c|}{ Anti-HCV (+) } \\
\hline & $\begin{array}{l}\text { Anti-HCV (-) } \\
(\mathrm{n}=1391,82.7 \%)\end{array}$ & $\begin{array}{l}\text { Anti-HCV(+) } \\
(\mathrm{n}=290,17.3 \%)\end{array}$ & $P$ value & $\begin{array}{l}\text { HCV RNA (-) } \\
(\mathrm{n}=76,26.2 \%)\end{array}$ & $\begin{array}{l}\text { HCV RNA }(+) \\
(\mathrm{n}=214,73.8 \%)\end{array}$ & $P$ value \\
\hline AST (IU/L), mean \pm SD & $19.4 \pm 10.3$ & $26.2 \pm 13.5$ & $<0.001$ & $21.4 \pm 10.4$ & $27.8 \pm 14.1$ & $<0.001$ \\
\hline $\operatorname{ALT}(\mathrm{IU} / \mathrm{L})$, mean $\pm \mathrm{SD}$ & $17.9 \pm 14.6$ & $26.3 \pm 18.4$ & $<0.001$ & $17.4 \pm 7.3$ & $29.5 \pm 16.0$ & $<0.001$ \\
\hline
\end{tabular}

* AST: aspartate aminotransferase; ALT: alanine aminotransferase

\section{Correlation with ASTIALT}

Traditionally, HD patients with either positive HBsAg or anti-HCV reactions were considered to be carrying HBV or HCV hepatitis. In this study, patients with sero-positive hepatitis markers (HBV or $\mathrm{HCV}$ ) had significantly higher AST/ALT levels than did their sero-negative counterparts (Table 2). We further divided the patients into viremic and non-viremic groups according to the presence of viral nucleic acid. Patients who were viremic (either HBV or HCV) had significantly higher AST/ALT levels than patients who were non-viremic (Table 2). Finding of fatty liver is common $(43 \%)$ and did not correlate with liver function in our series.

\section{Discussion}

It is well known that the overall prevalence rate of viral hepatitis in Asia, especially HBV and HCV hepatitis, remains higher than that in US and Europe, although some countries have become intermediate and low endemic areas of HBV infection because of their successful vaccination programs $(15,16)$. Taking Taiwan as an example, a population-based survey showed that the prevalence rate of HBsAg (+) still approached $12.9 \%$ although the national HBV vaccination had successfully lowered the sero-positive rate in children (17); anti-HCV $\left(^{+}\right)$was noted in $5.5 \% \sim 8.6 \%$ of all citizens, with regional differences $(18,19)$. The issue of viral hepatitis is especially serious in some specific subgroups of patients, such as the ones undergoing maintenance HD. In 2008, a national survey by Taiwan Society of Nephrology showed that the HBsAg $(+)$ rate in HD patients was $10.3 \%$, but anti-HCV $(+)$ rate was $18.5 \%$, which is $3-5$ times greater than that in the general population (20). In the US, the 2002 national surveillance showed an $8 \%$ of anti-HCV (+) rate in HD patients, five times greater than in the general population (21). Such a high prevalence was recognized to contribute to the HBV- and HCV-related liver diseases in these patients (22). Prevention of their transmission during HD is, there- fore, one of the major strategies. The current recommendations by the Centers of Disease Control and Prevention relied on strict adherence to infection control measures for the prevention of hepatitis virus transmission in the HD setting. Isolation of patients or the use of dedicated machines for $\mathrm{HBV} / \mathrm{HCV}$ infected patients was not recommended (23). However, no randomized controlled trials exist on the impact of isolation on the risk of transmission of $\mathrm{HBV} / \mathrm{HCV}$ to hemodialysis patients and it remains uncertain if such recommendations fit every country for prevention of transmission (24), especially in the highly prevalent areas. Therefore, the Taiwan Society of Nephrology has suggested the use of dedicated bed and machine for patients of $\mathrm{HBV}$ and $\mathrm{HCV}$ infections, besides the universal measures of infection control, in the guidelines for HD practice since 1990s. It was also suggested patients with hepatitis be dialyzed in separate areas to avoid cross-contamination by staff. The achieved effect was reflected by the low annual sero-conversion rate, $0.25 \%$ for $\mathrm{HBsAg}$ and $0.72 \%$ for anti-HCV. In Japan, the annual sero-conversion rate for anti-HCV was approximately $1.04 \%$ (25).

At present, the diagnosis of $\mathrm{HBV}$ and $\mathrm{HCV}$ infections in HD patients relies almost exclusively on HBsAg and anti-HCV serological tests. Comparative studies have questioned the accuracy of serological tests since the development of $\mathrm{HBV} / \mathrm{HCV}$ nucleic acids analysis. Certain rates of either false negative or false positive of both HBsAg and anti-HCV have been reported in the literature $(12,26)$. For example, Cabrerizo et al. showed that they could detect HBV DNA in $58 \%$ of HBsAg (-) HD patients (N=33) (27). Similar situations were also noted in non-HD populations (11). For $\mathrm{HCV}$, the chance of detecting $\mathrm{HCV}$ RNA in anti-HCV (-) patients was much less (12), but still present. In the present era of molecular medicine, the persistent dependence on serological tests for the accurate diagnosis of $\mathrm{HBV} / \mathrm{HCV}$ infection should be challenged, especially when it concerns the issues of disease transmission during HD (28). However, $\mathrm{HBV} / \mathrm{HCV}$ nucleic acids quantification is not gener- 
ally recommended by every national or international nephrology society, probably because international guidelines have to evaluate its application in countries with varied technical and economic competence. Nevertheless, 2008 KDIGO Guidelines has made a clear recommendation about the use of nucleic acid tests for units with a high prevalence of HCV (29). The current study is the first in Taiwan to include relative larger numbers of patients. The aim of this study is to demonstrate how the faithfulness of the presently used serological tests is when they are compared with the virological analysis. Our results showed that HBV DNA is absent in $42.2 \%$ of $\mathrm{HBsAg}(+)$ patients, and no HCV RNA can be detected in $26.2 \%$ of anti-HCV (+) patients. It was previously shown that background prevalence might influence the sensitivity and specificity of the serological tests (29). In high prevalent area, a high rate of false negative and a low rate of false positive might be expected (30). However, different from the reports in the literature $(12,27,30)$, a negative result of the serological tests in our series is also accompanied by negative result of $\mathrm{HBV} / \mathrm{HCV}$ nucleic acids in a subset of our cohort. Our findings showed that the so-called "silent hepatitis infection" patient, ie, actual existence of virus in the HBsAg (-) or anti-HCV (-) patients, was not present in our series. It raises a question concerning how we should define patients' status of hepatitis if they have a positive serological report, but do not have any detectable viral nucleic acid in their blood. In a strict sense of infection control, they are not infectious and will not transmit viral hepatitis. Yet, the answer would be uncertain if we consider the unstable and immuno-compromised states of the HD patients, and the basic difference of pathogenesis between $\mathrm{HBV}$ and $\mathrm{HCV}$. Our study group has planned to follow these patients longitudinally in order to reassure our conclusions and clarify this disputable issue. The information from the result of the present (and the future) study may be especially helpful for those countries with higher prevalence rates of $\mathrm{HBV} / \mathrm{HCV}$ hepatitis and for those where the dedicated bed/machine is an option.

In our series, HBV was with higher disproportion rate than $\mathrm{HCV}(42.2 \%$ vs $26.2 \%)$. We presume that the difference will mostly derive from the viral natures, DNA versus RNA virus. HBV viral genome can be incorporated into the human DNA in liver while HBV viral particles have been cleared from sera, and the viral genome may utilize the cellular machinery to constantly synthesize serum markers. On the contrary, HCV is an RNA virus and they do not hide in the human DNA. Immune system may still "remember" them, and keeps synthesizing anti-HCV antibodies after the HCV viremia is cleared.

It is well-recognized that chronic infection of
$\mathrm{HBV}$ and $\mathrm{HCV}$ contributes to potential higher risk of morbidity and mortality in the general population (1), and also in dialysis patients $(2,3)$. Clinical analysis in our study showed significantly higher six-month average levels of AST/ALT in patients with either "serological" or "virological" HBV/HCV. Chronic functional impairment potentially causes more serious clinical liver disease, that is, liver cirrhosis (LC) and hepatocellular carcinoma (HCC) (31). In Taiwan, an endemic country of viral hepatitis, the positive rates of HBsAg and anti-HCV in the general population were approximately $15.1 \%$ and $5.5-8.6 \%(18,19)$. For more severe liver disease, a population-based survey in Taiwan identified $0.97 \%$ prevalence for LC and $0.2 \%$ for HCC (32). Prevalence for LC in HD patients was $6.16 \%$ (33), at least six times higher than in the general population, and contributed a certain degree to their morbidity and mortality. Similar situations have been observed in other countries (6). Results of the present study are valuable in defining the truly infectious individuals and may help the nephrology societies in revising and adopting the management strategies toward $\mathrm{HBV} / \mathrm{HCV}$-infected patients.

Recently published papers concerning $\mathrm{HCC}$ in HD patients are more intriguing. HD patients had the same prevalence of HCC $(0.2 \%)$ as in the general population (34), in spite of 2-3 times higher HCV carrier rate and 6-7 times higher LC rate. Furthermore, they do not have worse long-term survival compared with the non-dialysis counterparts (35). Discussion about this counter-intuitive phenomenon is out of the scope of this article but is definitely another topic of research interest.

The present study has limitations in several aspects. First, we did not perform viral nucleic acid detection for every included patient and therefore, could not demonstrate the sensitivity and specificity for either serological tests or virological tests. Second, we had only performed viral detection in a subset of HBsAg (-) and anti-HCV (-) patients. Extrapolation of our finding to exclude the existence of "silent hepatitis infection" by using the updated serological kits is presently not rational. Another weakness is the lack of longitudinal follow-up data. Therefore, we are unable to understand if the discrepancy between the serological and virological diagnostic tests of $\mathrm{HBV} / \mathrm{HCV}$ would change over time. The present study cannot provide our own data of liver disease deterioration, ie, chronic liver disease to LC or HCC, and effect of anti-viral therapy on their outcome is not known (36). Another study is now underway and we might be able to answer some of the above-mentioned questions.

In summary, we found that the currently used serological tests (HBsAg and anti-HCV) show a high 
non-viremic rate for the diagnosis of $\mathrm{HBV} / \mathrm{HCV}$ infections (42.2\% for HBV and $26.2 \%$ for HCV) when they are compared with the viral nucleic acid quantitative tests. In a subset of our cohort, no viral nucleic acid was detected in 151 HBsAg (-)/167 anti-HCV (-) patients. We encourage HD institutes to examine HBV DNA for HBsAg $(+)$ patients, and HCV RNA for anti-HCV $(+)$ patients and reconsider the allocation of patients. The test results can be used to confirm the potential of $\mathrm{HBV} / \mathrm{HCV}$ transmission and to develop more efficient strategies in taking care of such patients, especially in countries with high prevalence rates of $\mathrm{HBV} / \mathrm{HCV}$.

\section{Acknowledgement}

This study was financially supported by a joint research project 100CM-KMU-09 by Kaohsiung Medical University Hospital and Chi Mei Medical Center. The authors want to thank Ms. Hua-Ling Yang and Ms. Yu-Ting Hsu for their technical assistance. We are grateful to have the participation of the following nephrology practitioners: Dr. Jung-Ming Yang, Dr. Ming-Hsing Sung, Dr. Shih-Pi Lin, Dr. Fei-Ching Lee, Dr. Chen-Tai Shen, and Dr. Chen-Hung Shih. All of the authors and contributors declare no financial conflict of interest.

\section{Competing Interests}

There is no conflict of interest in the information contained in this paper.

\section{References}

1. El-Serag HB. Epidemiology of viral hepatitis and hepatocellular carcinoma. Gastroenterology 2012; 142: 1264-73.

2. Tang S, Lai KN. Chronic viral hepatitis in hemodialysis patients. Hemodial Int 2005; 9: 169-79.

3. Fabrizi F, Messa P, Basile C, Martin P. Hepatic disorders in chronic kidney disease. Nat Rev Nephrol 2010; 6: 395-403.

4. Yang WC, Hwang SJ, and Taiwan Society of Nephrology. Incidence, prevalence and mortality trends of dialysis end-stage renal disease in Taiwan from 1990 to 2001: the impact of national health insurance. Nephrol Dial Transplant 2008; 23: 3977-82.

5. Zacks SL, Fried MW. Hepatitis B and C and renal failure. Infect Dis Clin North Am 2001; 15: 877-99.

6. Henderson WA, Shankar R, Gill JM, Kim KH, Ghany MG, Skanderson M, Butt AA. Hepatitis C progressing to hepatocellular carcinoma: the HCV dialysis patient in dilemma. J Viral Hepat 2010; 17: 59-64.

7. Practical Guidelines for Hemodialysis Treatment in Taiwan. Taiwan Society of Nephrology, 2004.

8. Paterlini P, Gerken G, Nakajima E, Terre S, D'Errico A, Grigioni W, Nalpas B, Franco D, Wands J, Kew M, Pisi E, Tiollais P, Brechot C. Polymerase chain reaction to detect hepatitis B virus DNA and RNA sequences in primary liver cancers from patients negative for hepatitis B surface antigen. N Engl J Med 1990; 323: 80-5.

9. Garson JA, Tuke PW, Makris M, Briggs M, Machin SJ, Preston FE, Tedder RS. Demonstration of viraemia patterns in haemophiliacs treated with hepatitis-C-virus-contaminated factor VIII concentrates. Lancet 1990; 336: 1022-5.

10. Michalak TI, Pasquinelli C, Guilhot S, Chisari FV. Hepatitis B virus persistence after recovery from acute viral hepatitis. J Clin Invest 1994; 93: 230-9.

11. Cacciola I, Pollicino T, Squadrito G, Cerenzia G, Orlando ME, Raimondo G. Occult hepatitis B virus infection in patients with chronic hepatitis $C$ liver disease. N Engl J Med 1999; 341: 22-6.

12. Rahnavardi M, Hosseini Moghaddam SM, Alavian SM. Hepatitis C in hemodialysis patients: current global magnitude, natural history, diagnostic difficulties, and preventive measures. Am J Nephrol 2008; 28: 628-40.

13. Lin YY, Huang JF, Liu SF, Yu ML, Tsai CH, Yang JF, Lin IL, Dai CY, Lin ZY, Chen SC, Chang WY, Chuang WL. Performance characteristics of two re- al-time PCR assays for quantification of hepatitis B virus DNA. Scand J Infect Dis 2009; 41: 614-8.

14. Vermehren J, Yu ML, Monto A, Yao JD, Anderson C, Bertuzis R, Schneider G, Sarrazin C. Multi-center evaluation of the Abbott RealTime HCV assay for monitoring patients undergoing antiviral therapy for chronic hepatitis C. J Clin Virol 2011; 52: 133-7.

15. Ott JJ, Stevens GA, Groeger J, Wiersma ST. Global epidemiology of hepatitis B virus infection: new estimates of age-specific HBsAg seroprevalence and endemicity. Vaccine 2012; 29: 2212-9.

16. Huang CF, Dai CY, Chuang WL, Ho CK, Wu TC, Hou NJ, Wang CL, Hsieh MY, Huang JF, Lin ZY, Chen SC, Hsieh MY, Wang LY, Tsai JF, Chang WY, Yu ML. HBV infection in indigenous children, 20 years after immunization in Taiwan: a community-based study. Prev Med 2009; 48: 397-400.

17. Hung HF, Chen TH. Probabilistic cost-effectiveness analysis of the long-term effect of universal hepatitis B vaccination: an experience from Taiwan with high hepatitis B virus infection and Hepatitis B e Antigen positive prevalence. Vaccine 2009; 27:6770-6.

18. Lee MH, Yang HI, Jen CL, Lu SN, Yeh SH, Liu CJ, You SL, Sun CA, Wang LY, Chen WJ, Chen CJ; R.E.V.E.A.L.-HCV Study Group. Community and personal risk factors for hepatitis $\mathrm{C}$ virus infection: a survey of 23,820 residents in Taiwan in 1991-2. Gut 2011; 60: 688-94.

19. Yang JF, Lin CI, Huang JF, Dai CY, Lin WY, Ho CK, Hsieh MY, Lee LP, Ho NJ, Lin ZY, Chen SC, Hsieh MY, Wang LY, Yu ML, Chuang WL, Chang WY. Viral hepatitis infections in southern Taiwan: a multicenter community-based study. Kaohsiung J Med Sci 2010; 26: 461-9.

20. Wu MS, Wu IW, Hsu KH. Survival analysis of Taiwan Renal Registry Data System (TWRDS) 2000-2009. Acta Nephrologica 2012; 26: 104-8.

21. Patel PR, Thompson ND, Kallen AJ, Arduino MJ. Epidemiology, surveillance, and prevention of hepatitis $C$ virus infections in hemodialysis patients. Am J Kidney Dis 2010; 56: 371-8.

22. Ohsawa M, Kato K, Tanno K, Itai K, Fujishima Y, Okayama A, Turin TC, Onoda T, Suzuki K, Nakamura M, Kawamura K, Akiba T, Sakata K, Fujioka T. Seropositivity for anti-HCV core antigen is independently associated with increased all-cause, cardiovascular, and liver disease-related mortality in hemodialysis patients. J Epidemiol 2011; 21: 491-9.

23. CDC. Recommendations for preventing transmission of infections among chronic hemodialysis patients. CDC MMWR Recomm Rep 2001; 50:1-43.

24. Fabrizi F, Martin P. Health care-associated transmission of hepatitis B and C viruses in hemodialysis units. Clin Liver Dis 2010; 14: 49-60.

25. Nakai S, Iseki K, Itami N, Ogata S, Kazama JJ, Kimata N, Shigematsu T, Shinoda T, Shoji T, Suzuki K, Taniguchi M, Tsuchida K, Nakamoto H, Nishi H, Hashimoto S, Hasegawa T, Hanafusa N, Hamano T, Fujii N, Masakane I, Marubayashi S, Morita O, Yamagata K, Wakai K, Wada A, Watanabe Y, Tsubakihara Y. An overview of regular dialysis treatment in Japan (as of 31 December 2010). Ther Apher Dial 2012; 16: 483-521.

26. Chemin I, Jeantet D, Kay A, Trépo C. Role of silent hepatitis B virus in chronic hepatitis B surface antigen (-) liver disease. Antiviral Res 2001; 52: 117-23.

27. Cabrerizo M, Bartolomé J, De Sequera P, Caramelo C, Carreño V. Hepatitis B virus DNA in serum and blood cells of hepatitis B surface antigen-negative hemodialysis patients and staff. J Am Soc Nephrol 1997; 8: 1443-7.

28. Teo CG. Changing strategies for hepatitis C testing. Antivir Ther 2012; 17: 1391-5.

29. Guideline 1: Detection and evaluation of HCV in CKD. Kidney Int 2008; 73 (suppl 109): S10-9.

30. Kalantar-Zadeh K, Miller LG, Daar ES. Diagnostic discordance for hepatitis C virus infection in hemodialysis patients. Am J Kidney Dis 2005; 46: 290-300.

31. McGlynn KA, London WT. The global epidemiology of hepatocellular carcinoma: present and future. Clin Liver Dis 2011; 15: 223-43.

32. Wu GH, Boucher BJ, Chiu YH, Liao CS, Chen TH. Impact of chewing betel-nut (Areca catechu) on liver cirrhosis and hepatocellular carcinoma: a population-based study from an area with a high prevalence of hepatitis $\mathrm{B}$ and $\mathrm{C}$ infections. Public Health Nutr 2009; 12: 129-35.

33. Chien CC, Wang JJ, Sun YM, Sun DP, Sheu MJ, Weng SF, Chu CC, Chen HA, Chio CC, Hwang JC, Lu YH, Wang HY, Kan WC. Long-term survival and predictors for mortality among dialysis patients in an endemic area for chronic liver disease: a national cohort study in Taiwan. BMC Nephrol 2012; 18: 13:43.

34. Lee YH, Hsu CY, Hsia CY, Huang YH, Su CW, Lin HC, Lee RC, Chiou YY, Huo TI. Hepatocellular carcinoma in uremic patients: Is there evidence for an increased risk of mortality? J Gastroenterol Hepatol 2013; 28:348-56.

35. Hwang JC, Weng SF, Weng RH. High incidence of hepatocellular carcinoma in ESRD patients: caused by high hepatitis rate or 'uremia'? a population-based study. Jpn J Clin Oncol 2012; 42: 780-6.

36. Yu ML, Lin SM, Chuang WL, Dai CY, Wang JH, Lu SN, Sheen IS, Chang WY, Lee CM, Liaw YF. A sustained virological response to interferon or interferon/ribavirin reduces hepatocellular carcinoma and improves survival in chronic hepatitis C: a nationwide, multicentre study in Taiwan. Antivir Ther 2006; 11: 985-94 